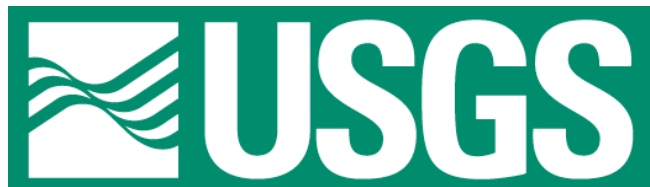

science for a changing world

Field-Trip Guide to Volcanic and Volcaniclastic Deposits of the Lower Jurassic Talkeetna Formation, Sheep Mountain, South-Central Alaska

U.S. Department of the Interior

U.S. Geological Survey

Open-File Report 2006-1124

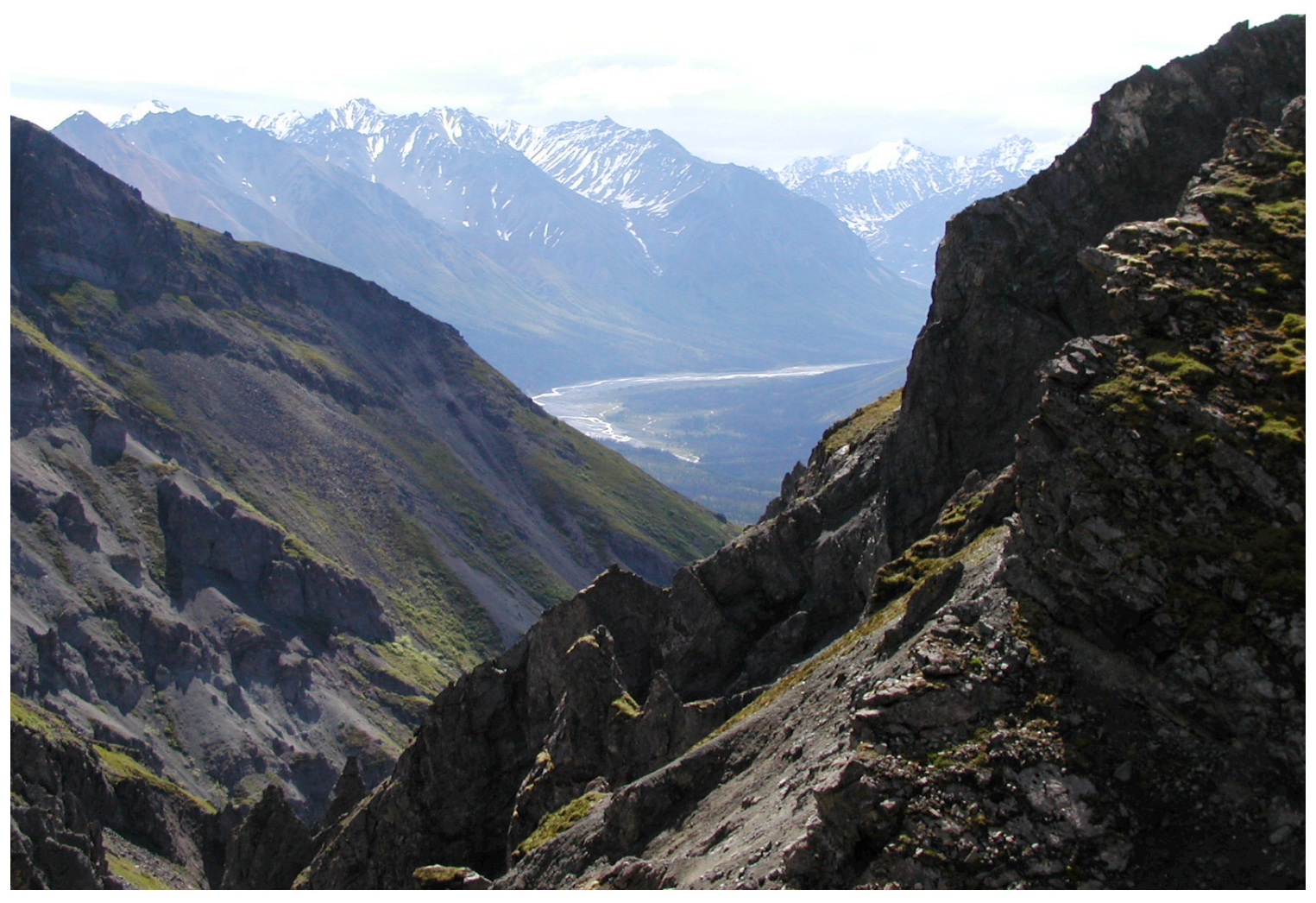




\title{
Field-Trip Guide to Volcanic and Volcaniclastic Deposits of the Lower Jurassic Talkeetna Formation, Sheep Mountain, South-Central Alaska
}

\author{
Amy E. Draut \\ U.S. Geological Survey, Pacific Science Center, Santa Cruz, CA 95060 \\ Peter D. Clift \\ School of Geosciences, University of Aberdeen, AB24 3UE, U.K. \\ Robert B. Blodgett \\ U.S. Geological Survey-Contractor, Anchorage, AK 99508
}

U.S. GEOLOGICAL SURVEY

Open-File Report 2006-1124 


\section{U.S. Department of the Interior}

\section{P. Lynn Scarlett, Acting Secretary}

\section{U.S. Geological Survey \\ P. Patrick Leahy, Acting Director}

U.S. Geological Survey, Reston, Virginia 2006

Revised and reprinted: 2006

Any use of trade, firm, or product names is for descriptive purposes only and does not imply endorsement by the U.S. Government

To download a copy of this report from the

World Wide Web: http://pubs.usgs.gov/of/2006/1124/

For more information on the USGS - the Federal source for science about the Earth, its natural and living resources, natural hazards, and the environment:

World Wide Web: http://www.usgs.gov

Telephone: 1-888-ASK-USGS

Although this report is in the public domain, permission must be secured from the individual copyright owners to reproduce any copyrighted material contained within this report. 


\section{LIST OF FIGURES}

FIGURE 1. Regional map of the field-trip area.

FIGURE 2. Geologic cross section through Sheep Mountain.

FIGURE 3. Stratigraphic sections on the south side of Sheep Mountain.

FIGURE 4. Stratigraphic sections on the north side of Sheep Mountain.

FIGURE 5. Photographs of Talkeetna Formation facies on Sheep Mountain.

FIGURE 6. Depositional environments within the Talkeetna Formation.

\section{ADDITIONAL DIGITAL INFORMATION}

For an online PDF version of this report, please see: http://pubs.usgs.gov/of/2006/1124/

For more information on the U.S. Geological Survey's Alaska Paleontological Database, please see: http://www.alaskafossil.org

\section{DIRECT CONTACT INFORMATION}

Regarding this Report:

Dr. Amy E. Draut (Research Geologist): $\quad$ adraut@usgs.gov

\section{REPORT REFERENCE}

Draut, A.E., Clift, P.D., and Blodgett, R.B., 2006, Field-trip guide to volcanic and volcaniclastic deposits of the Lower Jurassic Talkeetna Formation, Sheep Mountain, South-Central Alaska, U.S. Geological Survey Open-File Report 20061124, $21 \mathrm{p}$. 


\begin{abstract}
This guide provides information for a one-day field trip in the vicinity of Sheep Mountain, just north of the Glenn Highway in south-central Alaska. The Lower Jurassic Talkeetna Formation (Imlay, 1981), consisting of extrusive volcanic and volcaniclastic sedimentary rocks of the Talkeetna arc complex (Kelemen and others, 2003; Clift and others, 2005a), is exposed on and near Sheep Mountain. Field-trip stops within short walking distance of the Glenn Highway (approximately two hours' drive from Anchorage) are described, which will be visited during the Geological Society of America Penrose meeting entitled Crustal Genesis and Evolution: Focus on Arc Lower Crust and Shallow Mantle, held in Valdez, Alaska, in July 2006. Several additional exposures of the Talkeetna Formation on other parts of Sheep Mountain that would need to be accessed with longer and more strenuous walking or by helicopter are also mentioned.
\end{abstract}

\title{
Regional Geology of the Talkeetna Arc
}

The Jurassic Talkeetna crustal section of south-central Alaska (Fig. 1; Trop and others, 2002; Kelemen and others, 2003; Clift and others, 2005a) is the most complete volcanic-arc section exposed in any accreted arc to have been studied worldwide thus far. It includes $\sim 7 \mathrm{~km}$ of exposed section, similar to that observed seismically in the Tonga and Mariana Arcs (Suyehiro and others, 1996; Crawford and others, 2003). The Talkeetna Arc (Clift and others, 2005a) forms part of the Peninsular Terrane described by Plafker and Berg (1994), one of many terranes accreted to the active margin of North America during the Mesozoic and Cenozoic (for example, Gehrels and Berg 1994; Nokleberg and others, 1994). The Peninsular Terrane had amalgamated with two other oceanic terranes, the Alexander and Wrangellia Terranes, at least by Late Jurassic time ( 160 Ma; Gardner and others, 1988; Trop and others, 2002), forming the composite Wrangellia Terrane that subsequently accreted onto the North American continent during the Late Jurassic and Early Cretaceous (for example, Csejtey and others, 1982; Plafker and others, 1989; Nokleberg and others, 1994; Trop and others, 2002). The exact sequence of docking with Wrangellia and North America is not yet resolved, although it is clear that the Talkeetna Arc had collided with a terrane to its north by $\sim 160$ Ma when the coarse clastic Naknek Formation was deposited (Trop and others, 2005).

The lack of any significant continental sedimentary contribution to arc petrogenesis was interpreted by Clift and others (2005a) to indicate that the Talkeetna Arc could not have faced north while colliding with a North American passive margin. Moreover, the tectonically truncated arc section is juxtaposed against the Cretaceous accretionary complex to the south in the Chugach Mountains (Clift and others, 2005a, b), which suggests the presence of erosive 
plate boundary during the Early Jurassic, consistent with north-dipping subduction. The age and degree of deformation decreases progressively to the south within the accretionary prism, further implying protracted north-dipping subduction (Plafker and others, 1994).

The best radiometric age control on the Talkeetna Arc comes from the ages of plutons exposed along the southern boundary of the arc complex near the Border Ranges Fault (201-181 Ma), as well as from plutons in the Talkeetna Mountains to the NW (177-171 Ma; Rioux and others, 2003, submitted). Volcanic and volcaniclastic rocks of the Talkeetna Formation (Martin, 1926) were described by Winkler (1992), apparently based on misinterpretation of Kelley (1980), as "Upper Triassic (?) to Lower Jurassic" and this is the classification still used for this formation in the USGS database of stratigraphic nomenclature. However, no studies have confirmed a Late Triassic age for this unit and so we refer to it hereafter as Lower Jurassic. The lowermost volcaniclastic materials of the Talkeetna Formation have been dated as Hettangian (Early Jurassic, 200-196 Ma) based on ammonite fossils from exposures of the Talkeetna Formation on the Alaska Peninsula (Imlay, 1981; Poulton and others, 1992, Pálfy and others, 1999). Other volcaniclastic and quartzitic rocks of the Talkeetna Formation on the northeast side of Puale Bay on the Alaska Peninsula (Imlay 1981; Pálfy and others, 1999) have been dated as Hettangian to Lower Sinemurian (Lower Jurassic, 200-193 Ma). The precise stratigraphic relationship of these rocks at Puale Bay with those of the Talkeetna Formation to the north would benefit from further evaluation. Volcaniclastic rocks of the Talkeetna Formation in the Talkeetna Mountains (its type area) have been dated (Imlay 1981; Poulton and others, 1992) as Late Sinemurian to Toarcian (Lower Jurassic, 190-180 Ma).

The top of the Talkeetna Formation is, in most places, overlain unconformably by sandstones of the Middle Jurassic Tuxedni Group, which has been dated as Early Bajocian (172-168 Ma) on the basis of molluscan assemblages (Grantz 1960). There are few distinctive marker horizons within the Talkeetna Formation that would allow biostratigraphic age correlation between different exposed sections. However, the different facies found along and across strike of the exposure allow the paleogeography to be reconstructed, even if it is not possible to directly compare synchronous units in different regions. Within individual massifs there is no clear, coherent up-section facies evolution (Clift and others, 2005a).

The Talkeetna Formation and coeval mid-crustal gabbros were all generated in an oceanic setting, far from the influence of a continental magmatic source (Kelemen and others, 2003; Clift and others, 2005a; Greene and others, in press), similar to the western Pacific Tonga and Mariana Arcs. Although the polarity of Talkeetna subduction and the timing of its accretion to North America have been debated (Reed and others, 1983; Plafker and others, 1989; Wallace and others, 1989), there is little doubt that the arc was fully oceanic; Clift and others (2005b) have argued that it was likely also in a state of tectonic erosion. The juxtaposition of arc volcanic and plutonic rocks against younger accretionary material in the Chugach Mountains across the Border Ranges Fault is interpreted 
to reflect the loss of crust due to tectonic erosion before a switch to active subduction accretion during the Cretaceous (Plafker and others, 1994). Strikeslip faulting along the Border Ranges, Castle Mountain, and other associated faults in this area could have truncated the arc section in a horizontal direction but is thought not to have affected the vertical thickness of the formation; $\sim 5 \mathrm{~km}$ of Talkeetna Formation volcanic and volcaniclastic material is preserved in the Sheep Mountain massif alone, and there is no evidence for major thrusting or extension within Talkeetna Formation exposures at either Sheep Mountain, south of the Matanuska River, or farther north in the Boulder Creek, Horn Mountains, or Little Oshetna Valley areas (the sedimentology and geochemistry of which have been discussed in detail by Clift and others, 2005a).

As well as allowing study of arc volcaniclastic sedimentary rocks at greater depth than is possible in modern arcs, exposures of the Talkeetna Formation extend across and along the strike of the arc, allowing facies variability to be explored. In addition, the geochemical composition of the northernmost volcanic exposures in the Little Oshetna Valley are consistent with that of backarc deposits, and distinct from the main exposures of the arc farther south (Clift and others, 2005a). Clift and others, (2005a), following the observation of Burns (1985), argued that the oldest volcanic rocks in the Talkeetna Formation are exposed south of the Matanuska River, that the central part of the stratigraphy is exposed on Sheep Mountain, and that the upper part crops out in the East Boulder Creek area and in the Horn Mountains. The middle of the Talkeetna Formation exposed on Sheep Mountain (Fig. 2) is separated from the volcanic exposures south of the Matanuska River by an inferred strike-slip fault that follows the trend of the Matanuska River (also inferred by Grantz 1961). Although the presence of this fault could imply that some unknown volcanic thickness is missing from the section, the $7 \mathrm{~km}$ thickness reconstructed by Clift and others, (2005a) is consistent with paleobarometry constraints from the upper part of the gabbro section (B. Hacker, personal communication 2004), suggesting that the section is largely intact.

The Sheep Mountain massif consists almost entirely of Talkeetna Formation volcanic and volcaniclastic materials. Sheep Mountain itself is essentially a fault-bounded block, with various faults separating the Talkeetna Formation from Cretaceous sediments of the Matanuska Formation on the east and north (showing up-to-the-north stratigraphic displacement), an ENE-trending fault running through the Talkeetna Formation on the west side of Sheep Mountain, and the strike-slip fault inferred within Talkeetna Formation exposures along its south side.

About $13 \mathrm{~km}$ north of Sheep Mountain is the east-west trending Caribou Syncline, part of which (Syncline Mountain) is visible from the far eastern end of the described field-trip route. This broad syncline is in turn approximately $3-6 \mathrm{~km}$ south of the east-west trending Caribou Fault, which separates the Cretaceous Matanuska Formation (to the south) from a sequence of Jurassic (Naknek Formation) and Cretaceous sedimentary rocks, and Tertiary basalt flows and pyroclastic deposits. The Caribou Fault exhibits right-lateral strike-slip displacement that occurred before emplacement of the Eocene basalts, whereas 
later motion on this fault system has been largely vertical (up-to-the-north; Grantz 1961). Right-lateral strike-slip faulting along the Caribou and Castle Mountain Faults and their associated splays has offset volcanic exposures in the Talkeetna Formation, most notably in the East Boulder Creek area (Clift and others, 2005a). At Sheep Mountain, the base of the Talkeetna Formation exposures contain rare carbonate rocks and shales, and are dominated by medium-grained volcaniclastic sandstones that are interbedded with thick, matrix-supported tuff breccias. Sedimentary structures are rare but some shales are parallel-laminated and sandstones commonly grade upward into shale, suggesting possible deposition by turbidity currents. Higher in the section, volcaniclastic sandstones and shales are interbedded with very thick-bedded, clast-supported breccias, which are up to $20 \mathrm{~m}$ thick with clasts $>20 \mathrm{~cm}$ in diameter. Farther up-section, $\sim 3$ $\mathrm{km}$ from the section base, volcaniclastic rocks are interbedded with massive lavas and volcanic breccias that locally appear to be autobrecciated lavas. Lava units in this same area (the approximate middle of the Sheep Mountain stratigraphy) have amygdaloidal tops. These volcanic rocks in the middle of the section are typified by thickly bedded, matrix-supported, ungraded breccias up to $5 \mathrm{~m}$ thick, separated by minor shales each up to $30 \mathrm{~cm}$ thick. Clasts within the breccias are all angular, volcanic, and can be up to $70 \mathrm{~cm}$ in diameter. The uppermost $1 \mathrm{~km}$ of the section includes structureless, coarse-grained andesitic tuffs (Clift and others, 2005a) interbedded with 1-2-m-thick, massive vesicular basalts and basaltic andesite lavas. These, in turn, are overlain by a 12-m-thick matrix-supported tuff breccia, with vesicular clasts up to $60 \mathrm{~cm}$ across. A 10-mthick columnar-jointed basaltic unit caps this Sheep Mountain exposure, interpreted as a sill because of its geometry (Clift and others, 2005a).

The general depositional environment of the Sheep Mountain volcanic facies is interpreted to be proximal to volcanic centers. This proximal setting is inferred based on the high proportion of primary volcanic material (such as lavas and ignimbrites) the coarse-grained facies of breccia clasts and tuff deposits, and the lack of sorting evident in the abundant breccias. The paucity of sedimentary structures throughout most of these volcaniclastic units complicates interpretation of their depositional environment, though rare crossbedding indicates reworking by currents. Bivalve fossils in the westernmost and easternmost shale-rich exposures of the Talkeetna Formation on Sheep Mountain suggest that, where marine deposition occurred, water depths were likely no deeper than $\sim 500 \mathrm{~m}$ (outer shelf to upper bathyal environments); one such fossiliferous exposure is listed as the third stop on this field trip. Fossil terrestrial-plant leaves (including cycads) have also been found in isolated areas in the middle of the Sheep Mountain section, indicating some subaerial exposure and likely shallow water depths of sedimentation for much of the unit.

Figures 3 and 4 show stratigraphic logs made from the Sheep Mountain area; these logs represent five stratigraphic sections measured from canyons cut into the southwest, south-central, and east side of Sheep Mountain, as well as mapping work done along the southern ridge crest facing the Matanuska Valley, whereas Figure 4 represents one continuous section $>260 \mathrm{~m}$ thick measured in a canyon cut into the northeast side of Sheep Mountain. The total thickness of the 
Talkeetna Formation exposed on Sheep Mountain is estimated to be $>4 \mathrm{~km}$, of which $\sim 560 \mathrm{~m}$ are included in the detailed logs of Figures 3 and 4 . Sections logged on the north and south sides of Sheep Mountain contain similar proportions of primary volcanic material (73 percent overall, by bed thickness; the remainder consists of volcaniclastic material that has undergone some reworking). The Sheep Mountain sections are offset by multiple small-scale (<10 $\mathrm{m}$ offset) northwest-trending faults and are intruded by occasional dikes that may be part of a peperite complex (Busby-Spera and White, 1987); these complexes are associated with volcanism interacting with thick sedimentary sequences where magma has encountered water-saturated sediment and intrude into the sediment. The Talkeetna Formation at Sheep Mountain is dominated by proximal tuffs and matrix-supported breccias (Fig. 5), with minor lavas and volcaniclastic deposits (including occasional cross-bedded sandstones). Primary volcanic deposits include, on the south side of Sheep Mountain, thick (up to $\sim 20 \mathrm{~m}$ ) volcanic breccias and amygdaloidal, vesicular (zeolite-filled) lava flows. Some of these facies are visible in the area of Stop 2 on this field-trip route, on the south side of Sheep Mountain. Exposures on the north side of Sheep Mountain include structureless coarse-grained andesitic tuffs interbedded with basaltic and basaltic-andesite lavas (Fig. 5) that are overlain by a 12-m-thick matrix-supported breccia composed of clasts of tuff up to $60 \mathrm{~cm}$ in diameter. The uppermost unit of the Talkeetna Formation at Sheep Mountain is a basaltic lava flow up to $10 \mathrm{~m}$ thick with columnar jointing structures.

In addition to inferring a generally proximal volcanic depositional environment for the Talkeetna Formation at Sheep Mountain, Clift and others, (2005a) and Draut and Clift (2006) placed other Talkeetna Formation exposures into submarine depositional contexts based on comparison with modern arc analogs in the western Pacific. Figure 6 shows the inferred depositional settings for volcanic products of the Talkeetna Arc south of the Matanuska River, south of the Copper River basin (the basin being east of this field-trip area), at Sheep Mountain, and in the East Boulder Creek and Horn Mountains areas (both north of Sheep Mountain; see Fig. 1).

\section{Geology Visible from the Glenn Highway near Sheep Mountain}

Driving northeast on the Glenn Highway, nearing Sheep Mountain, the route will pass the Matanuska Glacier and its outwash plain. These will be visible on the right (south of the road) beginning around mile marker 101. There is a parking area with views of the glacier at mile marker 107.8 .

After passing the Matanuska Glacier the road turns northeast near mile marker 110, and there will be a view of the rock promontory that reaches 3185 feet known as the Lion Head (it looks more like a reclining lion when viewed from the east). The Lion Head is a Tertiary intrusion, one of several in the area. Two more similar intrusive bodies are visible to the east (elevation 3400 feet) and southeast (4032 feet), both due east of the Matanuska Glacier's outwash plain. 
These Tertiary intrusive bodies comprise felsic plugs and dikes of quartz porphyry and feldspar porphyry (Grantz, 1961); the Lion Head is surrounded by sediments of the Cretaceous Matanuska Formation and by Quaternary gravels.

Looking south across the Matanuska River near mile marker 110 the Chugach Mountains are visible. To the south in the foreground, the lower part of the Jurassic Talkeetna Formation arc volcanic stratigraphy is exposed; here the volcanic material is dominated by basaltic andesite lava (Fig. 3). At the western end of the exposures visible from this section of the highway, the Talkeetna Formation is in faulted contact with Cretaceous sediments. Some intrusive plutonic rocks (primarily intermediate but with minor felsic and mafic areas) of Jurassic-Cretaceous age have been mapped in this northern part of the Chugach Mountains.

Around mile marker 111 the Glenn Highway begins to traverse along the south/southeast side of Sheep Mountain. The southwesternmost of three summits on Sheep Mountain, reaching 6209 feet, is visible opposite mile marker 111. The road follows the northeast trend of the mountain along its base for approximately the next eight miles to its western end. The turn-off to Sheep Mountain Lodge is at mile 113.5. The summit north of Sheep Mountain Lodge reaches 6223 feet. The easternmost and highest peak on Sheep Mountain, the summit known as Gunsight Mountain, reaches 6441 feet and is visible opposite mile marker 116. At its eastern end (beginning around mile marker 117) black shales of the Matanuska Formation (Cretaceous) are visible, lying in faulted contact with the Talkeetna Formation.

After passing Sheep Mountain, the Glenn Highway continues northeast, entering the Copper River Basin approximately ten miles to the east.

\section{Field-Trip Stops}

Stop 1. Matanuska glacier overlook, near mile marker 108 on the Glenn Highway.

Stop 2. Approximately $1 \mathrm{~km}$ east of Sheep Mountain Lodge there is a long exposure above the road of well bedded volcaniclastic materials. Vehicles may be left in the gravel parking area on the north side of the highway. Upon climbing the slope above this parking area, a series of medium-bedded, coarse-grained mass-flow deposits becomes visible. These units comprise volcaniclastic sandstone and angular, poorly sorted breccias. The depositional environment is likely to be marine as evidenced by the presence of shales within sequences of coarser sandier breccias. Progressing east (up-section) across the ridge there is a 6-m-thick exposure of massive volcanic breccia, including blocks up to $1 \mathrm{~m}$ 
across. The angular character of the clasts, suspended in a sandy matrix, suggests a proximal origin, likely close to the volcanic center. Clasts include both fresh and weathered lavas, as well as volcanic sandstones. Continuing to the east, the slope exposes a series of well bedded shales and parallel laminated sandstones, which show normal grading. These are interpreted as turbidites, probably part of a proximal slope apron around the volcanic center. The sandstones contain grains of volcanic material, with no apparent quartz, mica, or other minerals of possible continental origin. Primary volcanic material includes airfall tuffs, largely of andesitic composition, although some darker colored units hint at a basaltic component as well. Lava flows are rare but one 8-m-thick massive flow is interbedded with the volcaniclastic rocks. Debate continues as to whether this unit might be an intrusive sill within a peperite complex (Clift and others, 2005a).

Moving further east and thus up-section the route comes to a prominent ridge of welded tuffs and sandy breccias. The sequence is well bedded, with a series of tuffs each ranging from $20-50 \mathrm{~cm}$ thick, and rare more massive lava flows. The ridge itself consists of a series of 4- to 5-m-thick dark-colored basaltic tuffs and crystalline tuffs. Tuff bed bases are typically sharp and commonly underlain by a conglomeratic layer, parallel-laminated sandstone, or breccia. The thickest tuff is $8 \mathrm{~m}$ thick and shows a columnar jointing pattern and curious vertical welded tubes that may be formed by fluid escape after rapid emplacement. Above this interval the Talkeetna Formation exposes a more reworked facies style, dominated by thin- to medium-bedded, commonly graded sandstones and laminated shales, consistent with deposition from turbidity currents and debris flows.

Stop 3. The second set of Talkeetna Formation outcrops that will be visited on this field trip is located on the east side of Sheep Mountain, just south of an unnamed drainage that lies directly south of Camp Creek. Sediment-rich units within the Talkeetna Formation contains many known fossil localities. See Martin (1926) and the Alaska Paleontological Database website (http://www.alaskafossil.org) for complete listing of all localities. Most of the localities contain marine fauna (i.e., ammonites; Imlay, 1983) and brachiopods (Sandy and Blodgett, 2000), although non-marine facies locally present that are rich in the remains of terrestrial plant fossils (Knowlton, 1916). Stop 3 is a fossil locality in the Talkeetna Formation that is relatively easily accessible by automobile, exposed approximately 400 feet above the road base of an abandoned section of the old Glenn Highway. It consists of sedimentary pockets (mostly mudstone and siltstone) located interstitially within a volcanic agglomerate. The locality can be accessed by driving roughly $6 \mathrm{~km}$ east of Sheep Mountain Lodge along the Glenn Highway, and then turning left onto an old abandoned stretch of the old Glenn Highway (the currently available 1:63,360 scale USGS topographic map shows only this old roadway), and then driving SW to where the old road crosses Camp Creek. Vehicles can be parked on the east side of the creek crossing, as the road is no longer passable at this point without a 4 -wheel-drive vehicle. The access to the outcrop then requires walking 
approximately $400 \mathrm{~m}$ to the southwest, crossing another smaller unnamed creek, then following a clearing on the north side of the creek that appears to represent an old game trail. This game trail leads northwest until it reaches the base of a prominent exposure of volcanic and agglomeratic rocks of the Talkeetna Formation. Careful searching of the exposure will show scattered pockets of sedimentary rocks that contain numerous brachiopods (roughly five or six species present, mostly belonging a single small rhynchonellid species, but also include three or four species of terebratulids and one spiriferoid), lesser bivalves, and rare ammonoids. Small outcrops of the Cretaceous Matanuska Formation containing large inoceramid bivalves are exposed along the game trail on the approach to the Talkeetna Formation outcrop, separated by a major high-angle fault according to the geologic map of Grantz (1961). The Talkeetna Formation fossil locality has the following GPS coordinates: Latitude $61^{\circ} 50.137^{\prime} \mathrm{N}$., longitude $147^{\circ} 25.364^{\prime}$ 'W with an approximate elevation of $3,900 \mathrm{ft}$.

\section{Acknowledgements}

Funding for Draut and Clift to study the Talkeetna Formation was provided by a grant from the National Science Foundation, Continental Dynamics program. Jeff Trop (Bucknell University) and Thomas Moore (USGS) provided constructive reviews of this manuscript.

\section{References}

Burns, L.E., 1985, The Border Ranges ultramafic and mafic complex, southcentral Alaska: Cumulate fractionates of island-arc volcanics: Canadian Journal of Earth Sciences, v. 22, p. 1020-1038.

Busby-Spera, C.J., and White, J.D.L., 1987, Variation in peperite textures associated with differing host sediment properties: Bulletin of Volcanology, v. 49 , p. $765-776$.

Clift, P.D., Draut, A.E., Kelemen, P.B., Blusztajn, J., and Greene, A., 2005a, Stratigraphic and Geochemical Evolution of an arc upper crustal section; the Jurassic Talkeetna Volcanic Formation, South Central Alaska: Geological Society of America Bulletin, v. 117, 902-925; doi: 10.1130/B25638.

Clift, P.D., Pavlis, T., DeBari, S.M., Draut, A.E., Rioux, M., and Kelemen, P.B., 2005b, Subduction erosion of the Jurassic Talkeetna-Bonanza Arc and the Mesozoic accretionary tectonics of western North America: Geology, v. 33, p. 881-884.

Crawford, W.C., Wiens, D.A., Hildebrand, J.A., Dorman, L.M., and Webb, S.C., 2003, Tonga Ridge and Lau Basin crustal structure from seismic refraction data: Journal of Geophysical Research, B, Solid Earth, v. 108, EPM 6, 17 p. 
Csejtey, B. Jr., Cox, D.P., Evarts, R.C., Stricker, G.D., and Foster, H.L., 1982, The Cenozoic Denali fault system and the Cretaceous accretionary development of southern Alaska: Journal of Geophysical Research v. 87, p. 3741-3754.

Draut, A. E. and Clift, P. D. 2006. Sedimentary processes in modern and ancient oceanic arc settings: evidence from the Jurassic Talkeetna Formation and the Mariana and Tonga arcs, western Pacific. Journal of Sedimentary Research, v. 76, DOI: 10.2110/jsr.2006.044.

Gehrels, G.E., and Berg, H.C., 1994, Geology of Southeastern Alaska, in Plafker, G., and Berg, H.C., eds., The Geology of Alaska: The Geological Society of America, The Geology of North America, vol. G-1, p. 451-467.

Grantz, A., 1960, A Geologic map of Talkeetna Mountains (A-1) Quadrangle, and the south third of Talkeetna Mountains (B-1) Quadrangle, Alaska: U.S. Geological Survey, Miscellaneous Geologic Investigations Map I-314, scale 1:25:000.

Grantz, A., 1961, Geologic map and cross sections of the Anchorage (D-2) quadrangle and the northeasternmost part of the Anchorage (D-3) quadrangle, Alaska: U.S. Geological Survey Miscellaneous Geological Investigations Map I-342, scale 1:48,000.

Greene, A.R., DeBari, S.M., Kelemen, P.B., Blusztajn, J., and Clift, P.D., in press, A detailed geochemical study of island arc crust: The Talkeetna Arc section, south-central Alaska: Journal of Petrology.

Imlay, R.W., 1981, Early Jurassic ammonites from Alaska: U.S. Geological Survey Professional Paper 1148, 49 p., 12 pls.

Kelemen, P.B., Hanghoj, K., and Greene, A.R., 2003, One view of the geochemistry of subduction-related magmatic arcs with an emphasis on primitive andesite and lower crust, in Rudnick, R.L., ed., The crust: Oxford, U.K., Elsevier-Pergamon, Treatise on Geochemistry, vol. 3, p. 593-659.Knowlton, F.H., 1916, A Lower Jurassic flora from the upper Matanuska Valley, Alaska: Proceedings of the U.S. National Museum, v. 51, no. 2158, p. 451-460.

Kelley, J.S., 1980, Environments of deposition and petrography of Lower Jurassic volcaniclastic rocks, southwestern Kenai Peninsula, Alaska: Ph.D. Thesis, University of California, Davis, $304 \mathrm{p}$.

Knowlton, F.H., 1916, A Lower Jurassic flora from the upper Matanuska Valley, Alaska: Proceedings of the U.S. National Museum, v. 51, no. 2158, p. 451-460.

Martin, G.C., 1926, The Mesozoic stratigraphy of Alaska: U.S. Geological Survey Bulletin 776, $493 \mathrm{p}$.

Nokleberg, W.J., Plafker, G., and Wilson, F.H., 1994, Geology of south-central Alaska, in Plafker, G. and Berg, H.C., eds., The Geology of Alaska: The Geological Society of America, The Geology of North America, vol. G-1, p. 311-365.

Pálfy, J., Smith, P.L., Mortensen, J.K., and Friedman, R.M., 1999, Integrated ammonite biochronology and $\mathrm{U}-\mathrm{Pb}$ geochronometry from a basal Jurassic 
section in Alaska: Geological Society of America, Bulletin, v. 111, p. 1537-1549.

Plafker, G. Nokleberg, W.J., and Lull, J.S., 1989, Bedrock geology and tectonic evolution of the Wrangellia, Peninsular, and Chugach terranes along the trans-Alaska crustal transect in the Chugach Mountains and southern Copper River basin, Alaska: Journal of Geophysical Research, v. 94, p. 4255-4295.

Plafker, G., Moore, J.C. and Winkler, G.R., 1994, Geology of the southern Alaska margin, in Plafker, G., and Berg, H.C., eds., The Geology of Alaska: The Geological Society of America, The Geology of North America, vol. G-1, p. 389-449.

Plafker, G.B., and Berg, H.C., 1994, Overview of the geology and tectonic evolution of Alaska, in Plafker, G., and Berg, H.C., eds., The Geology of Alaska: The Geological Society of America, The Geology of North America, vol. G-1, p. 989-1021.

Poulton, T.P., Detterman, R.L., Hall, R.L., Jones, D.L., Peterson, J.A., Smith, P., Taylor, D.G., Tipper, H.W., and Westermann, G.E.G., 1992, Part III Regional geology and stratigraphy, western Canada and the United States: in Westermann, G.E.G. (ed.), The Jurassic of the Circum-Pacific, p. 29-92.

Reed, B.L., Miesch, A.T., and Lanphere, M.A., 1983, Plutonic rocks of Jurassic age in the Alaska-Aleutian Range batholith: Chemical variations and polarity: Geological Society of America, Bulletin, v. 94, p. 1232-1240.

Rioux, M., Hacker, B., Mattinson, J., Kelemen, P., Plank, T., and Reiners, P., 2003, The evolution of silicic magmatism in the accreted Talkeetna arc, south-central Alaska: Implications for the growth of continents (abstract): Eos, Transactions, American Geophysical Union, AGU Fall Meeting, v. 84, p. 1546.

Rioux, M., Hacker, B., Mattinson, J., Kelemen, P., Blusztajn, J., and Gehrels, G., submitted, The magmatic development of an intra-oceanic crustal section: High-precision $\mathrm{U}-\mathrm{Pb}$ zircon and whole rock isotopic analyses from the accreted Talkeetna arc, south-central Alaska: Geological Society of America Bulletin.

Sandy, M. R., and Blodgett, R. B., 2000, Early Jurassic spiriferid brachiopods from Alaska and their paleogeographic significance: Geobios, v. 33, p. 319-328.

Suyehiro, K., Takahashi, N., Ariie, Y., Yokoi, Y., Hino, R., Shinohara, M., Kanazawa, T., Hirata, N., Tokuyama, H., and Taira, A., 1996, Continental crust, crustal underplating, and low- $Q$ upper mantle beneath an oceanic island arc: Science, v. 272, p. 390-392.

Trop, J.M., Ridgway, K.D., Manuszak, J.D., and Layer, P., 2002, Mesozoic sedimentary-basin development on the allochthonous Wrangellia composite terrane, Wrangell Mountains basin, Alaska: A long-term record of terrane migration and arc construction: Geological Society of America, Bulletin, v. 114, p. 693-717. 
Trop, J.M., Szuch, D.A., Rioux, M., and Blodgett, R.B., 2005, Sedimentology and provenance of the Upper Jurassic Naknek Formation, Talkeetna Mountains, Alaska: Bearings on the accretionary tectonic history of the Wrangellia composite terrane: Geological Society of America Bulletin, v. 117, p. 570-588.

Wallace, W.K., Hanks, C.L., and Rogers, J.F., 1989, The southern Kahiltna terrane: implications for the tectonic evolution of southwestern Alaska: Geological Society of America, Bulletin, v. 101, p. 1389-1407.

Winkler, G.R., 1992, Geologic map and summary geochronology of the Anchorage $1^{\circ} \times 3^{\circ}$ quadrangle, southern Alaska: U.S. Geological Survey Miscellaneous Investigations Map I-2283, scale 1:250,000. 


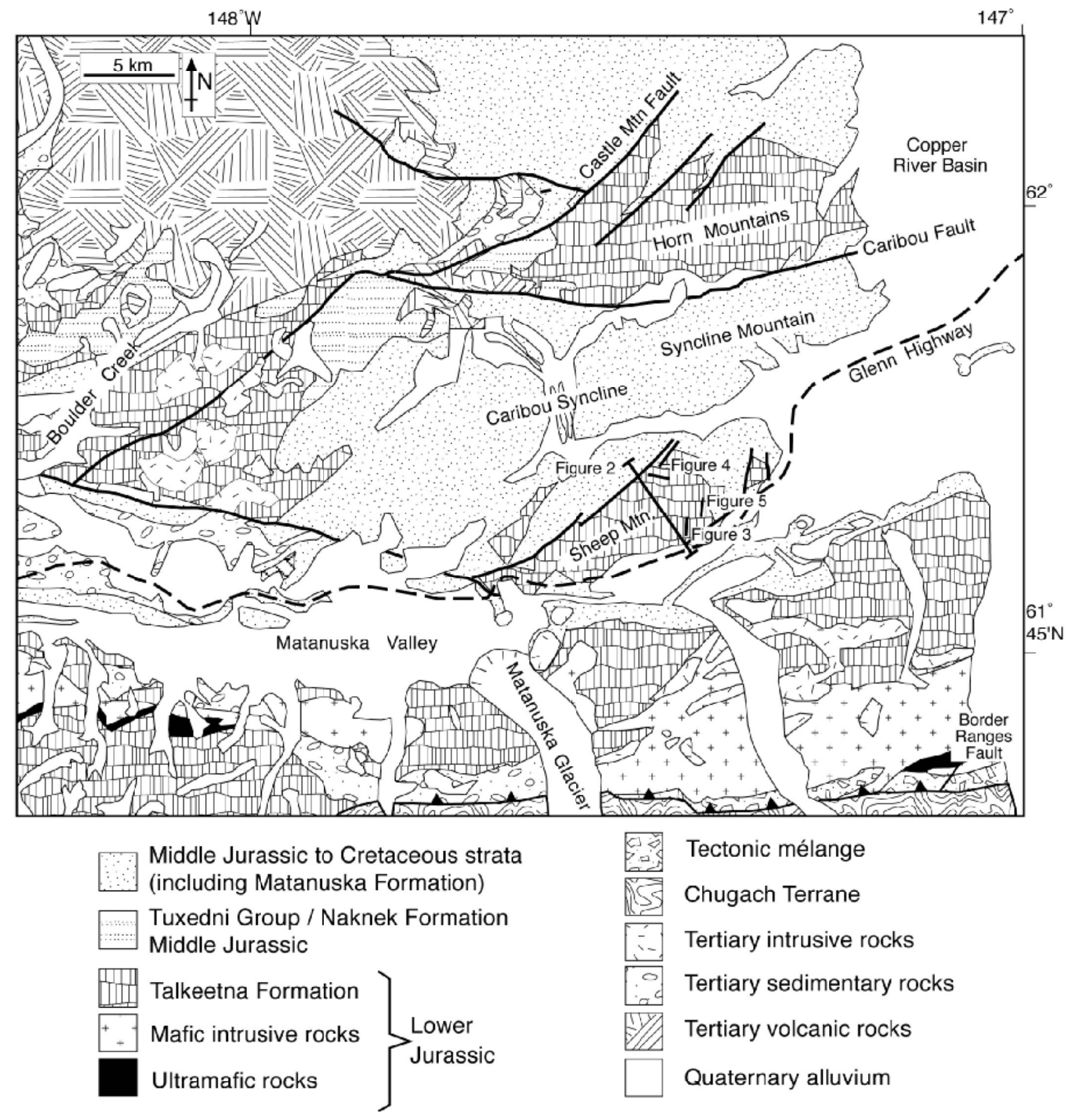

Figure 1. Regional map of the area northeast of Anchorage along the Glenn Highway where the Jurassic arc volcanic materials of the Talkeetna Formation are exposed. Locations of the cross section shown in Figure 2 is indicated, as are locations of stratigraphic sections shown in Figures 3 and 4. Locations of photographs that appear in Figure 5 are also noted. 


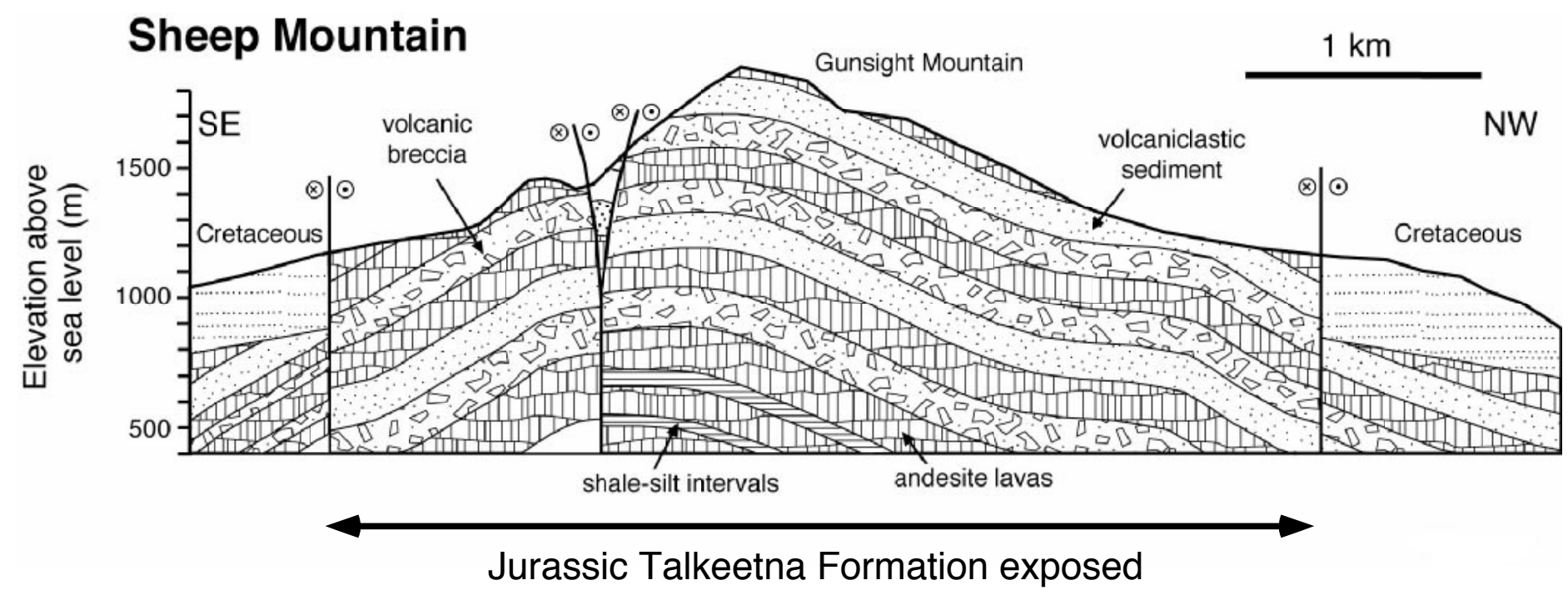

Figure 2. Cross section of the Sheep Mountain area, oriented northwest- southeast (Clift and others, 2005a). 


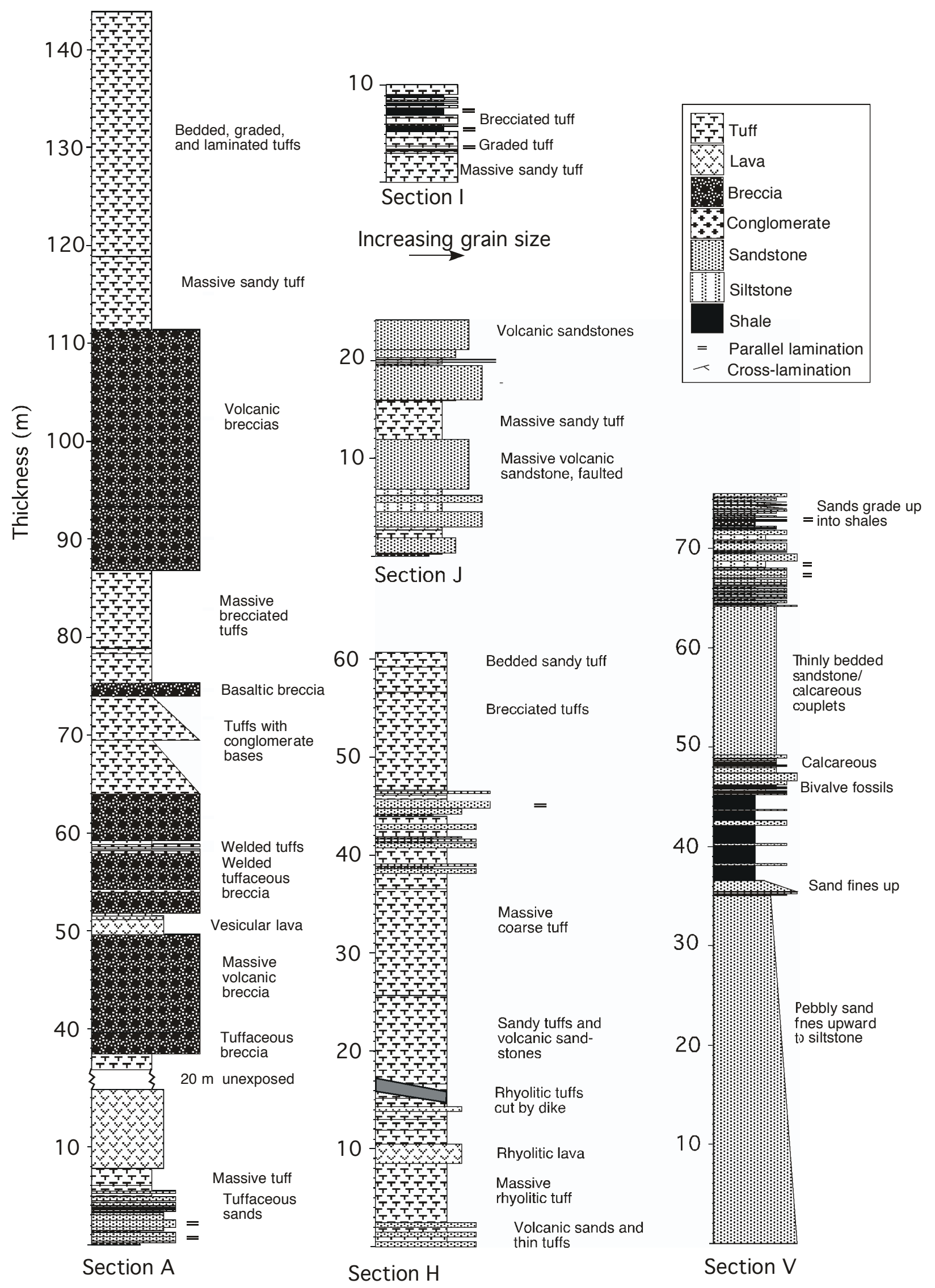

Figure 3. Stratigraphic sections on the south side of Sheep Mountain mapped by Clift and Draut during 2002 and 2003 (locations shown on Figure 1). These measured sections do not form one continuous section; several faults within the Sheep Mountain massif, combined with difficulties of access, preclude generation of one comprehensive stratigraphic column for the Talkeetna Formation at Sheep Mountain. 


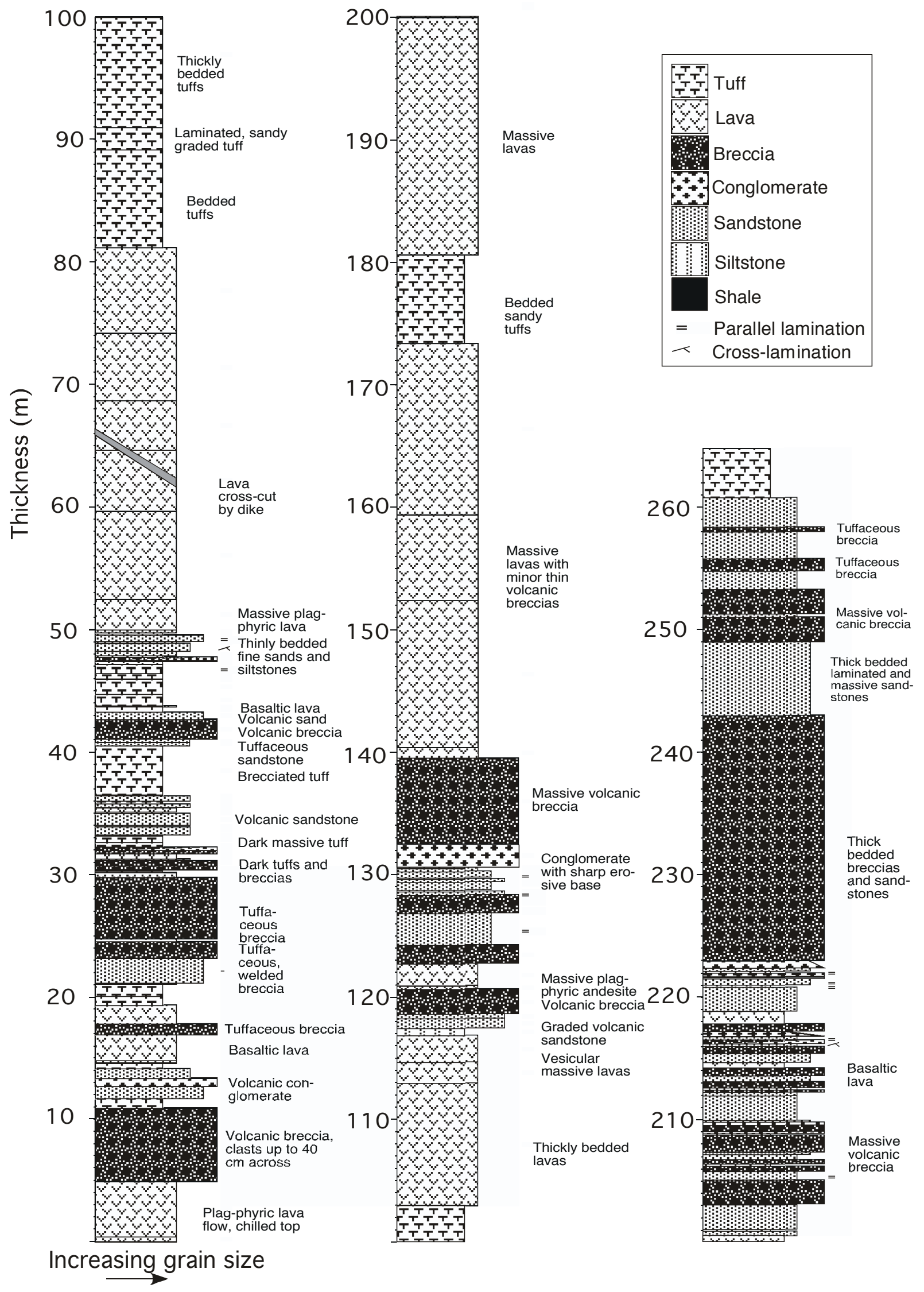

Figure 4. Continuous stratigraphic section measured on the north side of Sheep Mountain by Clift, Hanghoj, and Draut in 2002. 

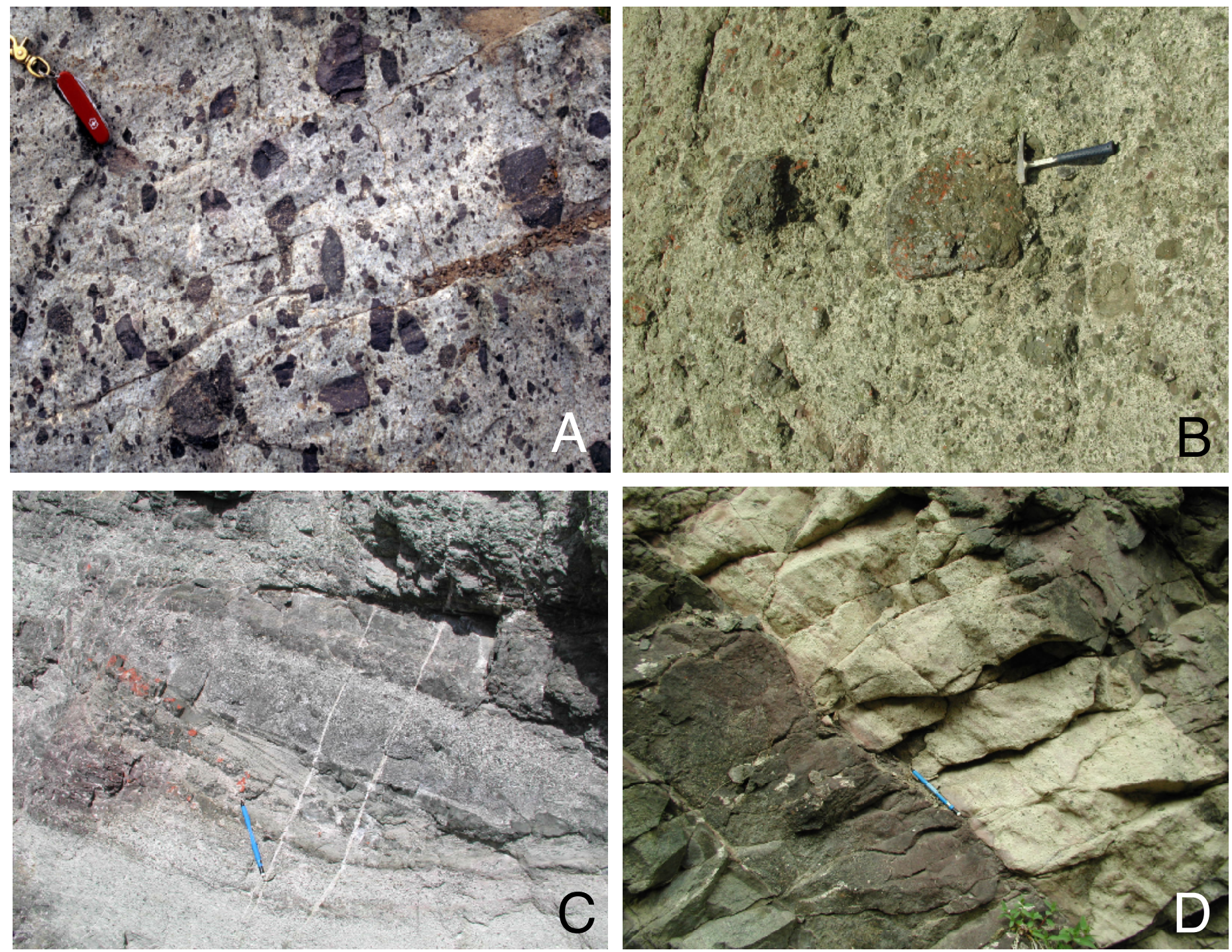

Figure 5. A: Proximal volcanic breccia unit within the Talkeetna Formation, mapped on the south side of Sheep Mountain. B: Volcanic breccia from the north side of Sheep Mountain. C: Volcaniclastic deposit on the south side of Sheep Mountain showing sedimentary structures that indicate current reworking. D: Light-colored coarse-grained tuff unit on Sheep Mountain, underlain and overlain by darker lava flows. 


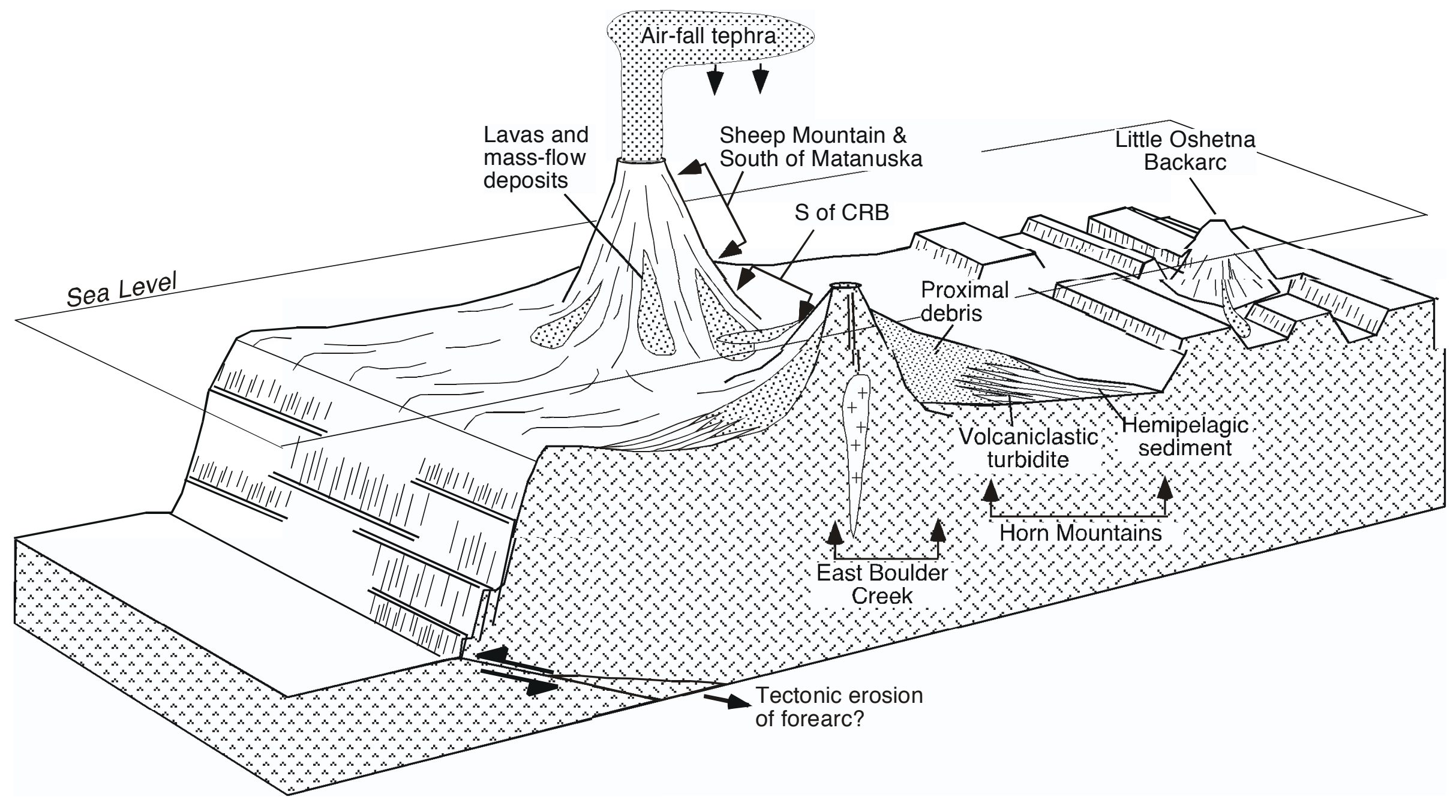

Figure 6. Schematic reconstruction of depositional environments for the arc volcanic and volcaniclastic Talkeetna Formation, from Draut and Clift (2006). Not to scale or actual compass orientation. 